\title{
Electrical energy production by using waste exhaust energy of internal combustion diesel engines
}

\section{İçten yanmalı dizel motorunun atık egzoz gazı enerjisi kullanılarak elektrik enerjisi üretimi}

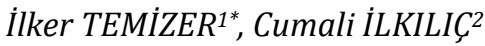 \\ ${ }^{1}$ Automotive Engineering Department, Technology Faculty, Cumhuriyet University, Sivas, Turkey. \\ itemizer@cumhuriyet.edu.tr \\ ${ }^{2}$ Automotive Engineering Department, Technology Faculty, Firat University, Elazig, Turkey. \\ cilkilic@gmail.com
}

Received/Geliş Tarihi: 05.01.2016, Accepted/Kabul Tarihi: 09.08.2016

* Corresponding author/Yazıșilan Yazar

doi: $10.5505 /$ pajes.2016.64935

Research Article/Arastırma Makalesi

\begin{abstract}
In this study, a prototype that works in accordance with the working principles of thermoelectric generator has been applied to the exhaust system of an internal combustion diesel engine. The aim is to transform heat energy that is discharged into the atmosphere into a usable electrical energy. Two different fluids have been used in the systems in order to create different temperatures that constitute the working conditions of thermoelectric module. One of them is the exhaust gases that are used to create a hot surface. The other fluid is cooling water that enables to create differential temperature that is necessary for thermoelectric module. 40 thermoelectric modules that are placed on octagonal structure composed of aluminum alloy material are connected to each other electrically. The performance of thermoelectric generation systems has been examined in terms of changing speed and load in the engine. At the same time, the vehicle battery has been charged by transferring the electrical energy to converters.
\end{abstract}

Keywords: Waste heat recovery, Thermoelectric generation, Diesel engine

\section{Introduction}

Thermoelectric systems proposes a unique power generation solution because they convert thermal energy into electricity. The conversion of electrical energy from waste energy sources is very important for vehicles. The presence of thermoelectric generation (TEG) systems that can be alternative to alternators in the point of electrical energy production in the vehicles is important because TEG systems only use residual heat energy of the engine. Thermoelectric module (TEM) that provides the transfer of heat energy into electrical energy has got many important advantages such as being quiet, lack of pollutant impacts and moving parts and long working hours [1]-[3].

The performance of TEG systems are associated with the combustion in the engine and exhaust gases. As we know, a certain percentage of the energy obtained by using fuel-air mixture in internal combustion engines becomes useful work A portion of the heat energy resulting from the burning is thrown into environment by cooling water, exhaust gas and radiation. Thus, a large percentage of the energy generated in the engine is not used [4].

Combustion in the internal combustion engines is a physicochemical process formed in the gas phase in a very short time. Exhaust process starts with the opening of a specific advance of exhaust valve at the end of the combustion process
Öz

Bu çalıșmada, termoelektrik jeneratörlerin çalıșma prensiplerine uygun olarak çalışan bir prototip geliștirilerek içten yanmalı dizel bir motorun egzoz sistemine uygulanmistır. Amac, egzoz gazlarıla atmosfere atılan ıSı enerjisini kullanılabilir bir elektrik enerjisine dönüştürmektir. Termoelektrik modüllerin çalıșma șartı olan fark sıcaklıklarını oluşturmak amacıyla sistemde iki farklı akışkan kullanılmıştır Bunlardan ilki, sıcak yüzey şartını oluşturmak için kullanılan egzoz gazlarıdır. Diğer akıșkan ise, termoelektrik modüllerde ihtiyaç duyulan fark sıcaklığının oluşmasını sağlayan soğutma suyudur. Malzemesi alüminyum alașim olan sekizgen yapıya yerlestirilen 40 adet termoelektrik modül kendi aralarında elektriksel olarak seri bağlanmıștır. Motorda değișen devir ve yük durumuna göre termoelektrik jeneratör sisteminin performansı incelenmiştir. Ayn zamanda, termoelektrik jeneratör sisteminin ürettiği elektrik enerjisi konvertöre aktarılarak araç aküsü șarj edilmiștir.

Anahtar kelimeler: Atık ısı dönüșümü, Termoelektrik jeneratör, Dizel motor

and it ends with the closing of the exhaust valve [5]. The heat energy of gases that leave the cylinders in a certain speed and temperature is an important potential. For this reason, the works in the field of recovery of waste energy are gaining importance day by day because the comfort provided by the vehicles is increasing day by day depending on the demands of the customers and progress of the technology. The energy consumption in the vehicles is increasing in parallel with the increased comfort. This increase provides vehicle alternators to increase the power generation capacity. For this reason, the alternative power generation production should have adequate quality to meet this increase [6]. In recent studies, the systems and equipment on transferring the waste heat energy have been discussed. The method of using the waste heat is an alternative solution in order to meet the need of electricity. In the case of installing a system based on exhaust system, the continuity of the energy will be provided and the emissions of greenhouse gases in the environmental dimension will be reduced. In many studies, it has been discussed that the electrical energy produced by thermoelectric generators may have an important effect to meet a part of the energy produced by the alternator [7]. In the study conducted on this basis, 18 TEG modules have been placed on the system that geometrically has rectangular structure. Three bulbs that have $25 \mathrm{~W}$ as electrical load and one bulb that has-15 W have been connected to the system. The vane hasn't been used for 
exploitation of the energy of exhaust gases in the system. It is thought that the using of vane increases the back-pressure of exhaust gas and it affects the engine negatively [8]. In many studies, the effect of the heat on pressure decrease of gas flows has been emphasized as a negligible level. Therefore, there are no serious pressure changes when the pressure values of exhaust gases in the engine with TEG system are examined [12]-[14]. Significant improvements in the recycling of exhaust gases and thermoelectric systems produced for vehicle applications have been obtained. The system where the temperature of exhaust gas is $600{ }^{\circ} \mathrm{C}$ and output power is 125 $\mathrm{W}$ has been adapted to single-cylinder engine [15]. Thermoelectric systems expressed by the academic studies have put the firms in a competitive environment commercially. It is possible to meet a great number of modules in different models and brands on the market for sale. In another study, it has been obtained that TEM that has got TEP1-1264-1.5 model has produced maximum $3 \mathrm{~V}$ voltage, $0.637 \mathrm{~A}$ current and $1.91 \mathrm{~W}$ power in the temperature of $200^{\circ} \mathrm{C}$ and the module with TMG-450-0.8-1.0 has produced maximum $8.97 \mathrm{~V}$ voltage, $0.41 \mathrm{~A}$ current and $3.742 \mathrm{~W}$ power in the temperature of $200{ }^{\circ} \mathrm{C}$. In addition, it has been observed that the different electrical loads have been applied to the modules and different output power has been formed [16]. In another study, the losses generated by thermoelectric generator system that will be used in internal combustion engines have been discussed. Fans and pumps used for additional cooling system are considered as a loss in thermoelectric systems. An internal combustion engine used with TEG system that provides energy recycling has been developed by Modelica Library-based model. In this model, useful power values have been determined for two different thermoelectric modules used for commercial. Electrical power values created by $\mathrm{Bi}_{2} \mathrm{Te}_{3}$ and $\mathrm{PeTe}$ based thermoelectric modules have been found as $180 \mathrm{~W}$ and $310 \mathrm{~W}$ [17]. Commercial software package programs that have been analyzed by using finite element method of TEM contribute to the studies in this field [18].

The flow-type in thermoelectric system is also extremely important. In another study carried out in this field produced a maximum power of $63.18 \mathrm{~W}$ in a 5 -layer counter flow prototype [19]. Recently, the thermoelectric power generation has become one of important research topics. The power generation system based geothermal resource has been designed using thermoelectric generator (TEG) modules. This system assembled with TEG modules had an installed power of $1 \mathrm{KW}$. But, an output power of over $160 \mathrm{~W}$ has been generated under a temperature difference of $80^{\circ} \mathrm{C}$ [20].

\subsection{Thermoelectric}

Thermoelectric is the science that examines the electrical potential that is composed on the materials due to the temperatures of the liquid or solid materials. Thermoelectric is the transformation of the temperature energy into electrical energy or electrical energy into temperature energy. The sub conducts have different temperatures when the electric current that passes through the circuit that is composed of the chemical procedures of the two different sub conductible materials that are connected to each other. The sub conductible that has two different points which have different temperatures, at the same time produce an electrical voltage [9]-[11]. The semi conductible that has different temperatures at the same time, a variety of effects occur. These are the Seebeck, Peltier, Thompson, Joule and Fourier effects. The physical principles, that make up the foundation of thermoelectric goes back to the 1800's. The scientists that have worked in this field up until today have insisted on the maximum material factor value (ZT). This factor consists of the consideration of materials' conductibility of electric and temperature when producing electricity from heat. The Seebeck effect is described as the transformation of various heats into electricity [21]-[22]. TEG is composed of two ceramic plates that serve as a foundation, providing mechanical integrity, and electrical insulation for $n$-type (heavily doped to create excess electrons) and $p$-type (heavily doped to create excess holes) semiconductor thermo elements. The structure of a typical one TEM is shown schematically in Figure 1. The Electrical power output depends upon the temperature difference, the properties of the semiconductor materials, and the load resistance.

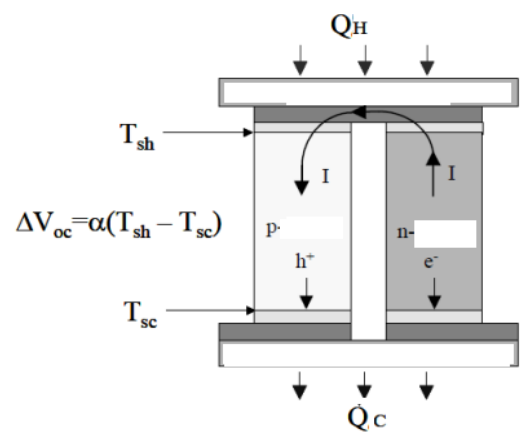

Figure 1: Thermoelectric couple [20].

To obtain a good electric conductor, the electrodes are usually made of metals or their alloys. When hot exhaust from the engine passes through an exhaust TE, the charge carriers of the semiconductors within the generator diffuse from the hot-side heat to the cold-side. As shown in Figure 2, a typical thermoelectric module contains both n-type and p-type thermoelectric materials connected in series. Thermoelectric couple is consists of two 'pellets' materials usually made from Bismuth Telluride. These are arranged electrically in series and thermally in parallel. When a temperature difference is created between the hot and cold junctions of two dissimilar materials (metals or semiconductors) a voltage is generated [23]-[25].

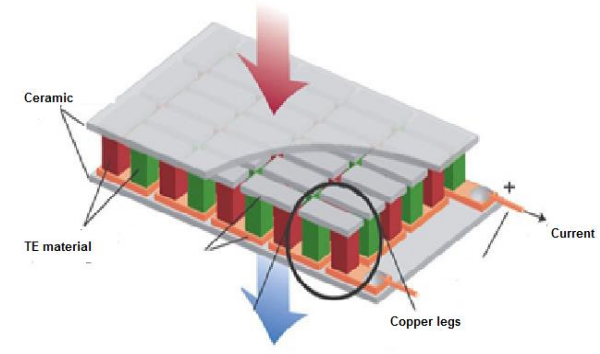

Figure 2: Termoelectric module [32].

Thermoelectric modules are used to convert thermal energy from different temperature gradients existing between hot and cold ends of a semiconductor into electric energy [23]-[25].

The performance of thermoelectric materials can be expressed as;

$$
Z=\frac{a^{2}}{k \cdot R}
$$

Where $Z$ is the thermoelectric material figure-of-merit, $a$ is the Seebeck coefficient given by, $R$ is the electric resistivity and $k$ is the total thermal conductivity. 


$$
a=\frac{\Delta v}{\Delta T}
$$

Heat transfer is towards cold surface from hot surface while the effect of thermoelectric, some events such as Kelvin relation, Joule statement and Fourier heat transfer statement have been developed. It is possible to express these effects in the below equations. These assumptions give the following thermoelectric (TE) equations for the heat released on the cold side, Qc, the heat absorbed on the hot side, Qh, and for the generated electrical power $\mathrm{P}$ [27]-[31].

$$
\begin{gathered}
\mathrm{Q}_{\mathrm{h}}=\alpha \cdot \mathrm{T}_{\mathrm{h} . \mathrm{I}}-0.5 \mathrm{I}^{2} \mathrm{R}+\mathrm{K} \cdot \Delta \mathrm{T} \\
\mathrm{Qc}=\alpha . \mathrm{Tc} . \mathrm{I}+0.5 \mathrm{I} 2 \mathrm{R}+\mathrm{K} . \Delta \mathrm{T} \\
\alpha=|\alpha \mathrm{n}|+|\alpha \mathrm{p}| \\
\mathrm{R}=\rho_{\mathrm{n}}\left(\mathrm{L}_{\mathrm{n}} / \mathrm{A}_{\mathrm{n}}\right)+\rho_{\mathrm{p}}\left(\mathrm{L}_{\mathrm{p}} / \mathrm{A}_{\mathrm{p}}\right) \\
\mathrm{k}=\lambda_{\mathrm{n}}\left(\mathrm{A}_{\mathrm{n}} / \mathrm{L}_{\mathrm{n}}\right)+\lambda_{\mathrm{p}}\left(\mathrm{A}_{\mathrm{p}} / \mathrm{L}_{\mathrm{p}}\right) \\
\Delta \mathrm{T}=\mathrm{T}_{\mathrm{h}}-\mathrm{T}_{\mathrm{c}} \\
\mathrm{I}=\alpha \Delta \mathrm{T} /\left(\mathrm{R}+\mathrm{R}_{0}\right)
\end{gathered}
$$

Where $P$ is electrical power $(\mathrm{W}), I$ is current $(A), V$ is voltage $(V)$, heat flow $Q_{H}$ is heat surface (W), heat flow $Q_{C}$ is cold surface (W), $\mathrm{R}$ is internal electrical resistance of TEM $(\Omega), R_{0}$ is load resistance, $\rho$ is $\mathrm{p} / \mathrm{n}$ type material density. Ln, Lp and Sn, Sp are respectively the leg length and cross-sectional area of the pellets.

$$
\mathrm{P}=\sum_{\mathrm{i}=1}^{\mathrm{N}}(\text { a. I.Tsh }- \text { a. I. Tsc })
$$

The efficiency of a thermoelectric module for power generation can be found by;

$$
\int=\frac{P}{Q h}
$$

The exhaust gas system of an engine is used to discharge the expanded exhaust gas through the exhaust manifold. Thermoelectric modules are applicable at the exhaust pipe, exhaust muffler, exhaust manifold and catalytic converter. In this study, the effect of diesel engine that is operated in different speed and load on TEG system has been researched. One of the most important points is the design of TEG system because the design of the system directly affects the efficiency of TEG systems [26]. The design should not create any negative effect on the engine. From this point, the important aspect in the design of the system is as follows:

- Thermal forces need to have the ability to distribute and manage as compared to a more planar design,

- Heat exchanger should be applied to the cold side in order to ensure the thermal conductivity, electrical insulation and water tightness,

- Exhaust gases have edge length that will not increase the surface and the opportunity to benefit from TEM,

- Input and output nozzles have been created in order to ensure the entry and exit of the exhaust gas flow. In this way, the negativity of sudden contraction and expansion has been prevented,
- Similar properties are considered to be important parameters in the selection of this geometry.

\section{Experimental setup}

Experiments are carried out by using Cussons P8602 brand engine dynamometer (test cell) bench and Fiat Doblo 1.9 Multijet brand diesel engine with 4 -cylinders and 4-stroke. Hydraulic dynamometer that controls the speed and load values of diesel engine is connected in order to determine the performance of TEG system placed between exhaust manifold and muffler. The objective is to determine the effect of engine on TEG system. The engine that is operated at different speeds has been run in 3 different loads as 50, 75 and 100 N.m. The output and input temperatures of exhaust gases have been recorded by measuring TEM top and low surface temperatures and voltage and current values. The features of internal combustion diesel engine connected to the test stand are given in Table 1.

Table 1: The engine's features used in the experiments.

\begin{tabular}{ll}
\hline Engine & Diesel P8602 Fiat Doblo \\
\hline Engine technology & Multijet 2, Turbocharged \\
Fuel System & Common Rail \\
Number of cylinders & 4 \\
Cylinder volume & 1.91 \\
Maximum torque & $2000 \mathrm{rpm}, 280$ N.m \\
\hline
\end{tabular}

\subsection{Design of TEG}

Thermoelectric generators are an intriguing way to generate renewable energy directly from waste heat. However, their efficiencies are limited owing to their thermal and electrical

\begin{tabular}{|c|c|}
\hline $\begin{array}{l}\text { System } \\
\text { Components }\end{array}$ & Dimensions \\
\hline Nozzle & $\begin{array}{l}\text { Length: } 150 \mathrm{~mm} \text {, Shrinkable cross- } \\
\text { sectional diameter: } 57 \mathrm{~mm} \text {, } \\
\text { Height: } 144.8 \mathrm{~mm} \text {, Thickness: } 2 \mathrm{~mm}\end{array}$ \\
\hline $\begin{array}{l}\text { Octagon } \\
\text { channel }\end{array}$ & $\begin{array}{l}\text { Length: } 300 \mathrm{~mm} \text {, Height: } 14.48 \mathrm{~mm} \text {, } \\
\text { Thickness: } 2 \mathrm{~mm}\end{array}$ \\
\hline Cylinder tube & $\begin{array}{l}\text { Length: } 300 \mathrm{~mm} \text {, İnner diameter: } 180 \\
\text { mm, Thickness: } 15 \mathrm{bmm}\end{array}$ \\
\hline TEM & $\begin{array}{l}56 \mathrm{~mm} \times 56 \mathrm{~mm} \times 5 \mathrm{~mm} \text { (Width, Length } \\
\text { and Thickness) }\end{array}$ \\
\hline $\begin{array}{l}\text { Total volume } \\
\text { octagon }\end{array}$ & $53448 \mathrm{~mm}^{3}$ \\
\hline
\end{tabular}
properties that are dependent on each other. Thermoelectric generation is shown in Figure 3. TEG should consist of the following components: heat exchanger, cooling system, thermal grease, Direct current to Direct current (DC/DC) converter and battery. The TEG module with 252 pairs of TE legs employed in this application. Hot side is rated to a maximum of $320{ }^{\circ} \mathrm{C}$ continuous. The weight of a single thermoelectric module is 60 grams. The dimensions of TEG are seen in Table 2.

Table 2: The dimensions of TEG.

The sensitivity to the coolant temperature is especially high since the thermoelectric efficiency increases with the decreasing cold side temperature. In the experiments, plate and cylinder tubes that consist of 6061 aluminum material have been used. The material selection has been done by considering the machinable features, corrosion resistance, lightness, flexibility and heat transfer parameter. Originally, aluminum plate that is cut in the measurement of $300 \times 480 \times 2 \mathrm{~mm}$ has 
been turned into an octagonal structure in the specific bending machine in order to make the angle of it as 135 degree. Fins are used to affect performance of the engine at system. The dimensions of TEG system are given in Table 2. Octagon provides to range the thermoelectric modules that their measurements are $5.6 \times 5.6 \times 5 \mathrm{~mm}$ side by side. Totally, 40 TEM have been connected between them as being 5 pieces in each surface in the experiments, as shown in Figure 3.

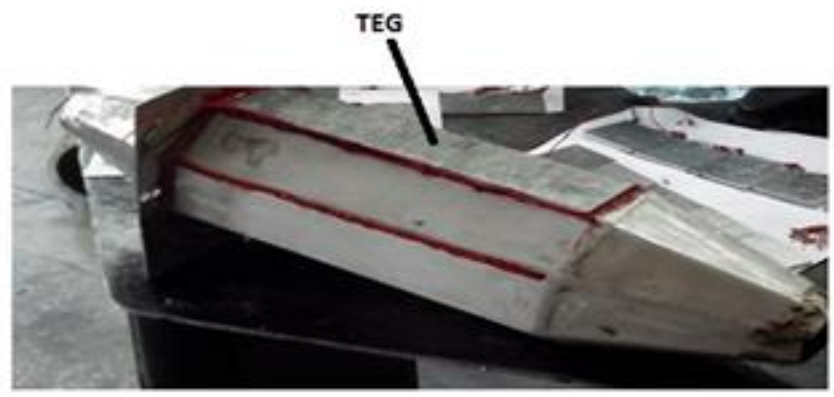

Figure 3: Thermoelectric generation.

The heat of exhaust gases in the octagon channel enable an opportunity to create hot surface of TEM. Water has been used in order to create the cold surface of TEM in the system. The three dimensional views of TEG System are shown in Figure 4.

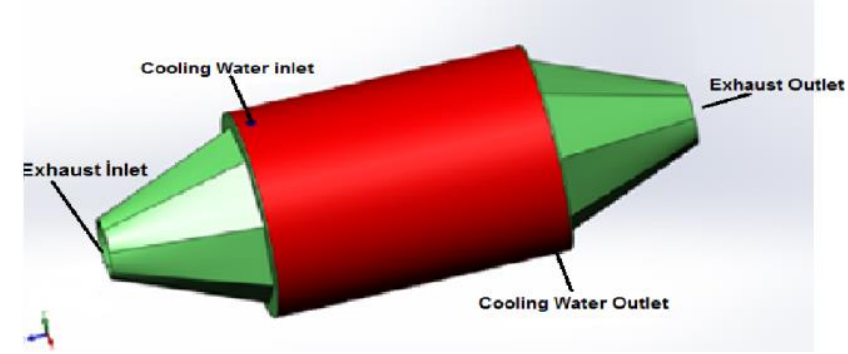

Figure 4: 3-dimensional view in the Solid Works program of TEG system.

Internal wall has been created with a thickness of $0.4 \mathrm{~mm}$ galvanized sheet between TEM's by using cold water that flows parallel with the exhaust gas flow. The objective is to prevent the damage of TEM by avoiding its contact with the water. Thermal paste used in order to recover the heat transfer and fill the microscopic gases on both surfaces of TEM. The input speed of cooling water is stable and $2 \mathrm{~m} / \mathrm{sec}$. in all working conditions. The one changing feature of cooling water is input heat. TEG cooling system consists of cooling radiator, hoses, tank and electric pump with $12 \mathrm{~V}$ DC voltage. DC/DC converter is in between TEG and battery as an electrical circuit. DC/DC converter under the brand of Mean Well brand with the number of SD-1000L-12 that enables to charge the battery in a certain voltage was used as damper to prevent the power fluctuations and transfer the electrical power. The distance of working voltage of convertor is between 19-72 V. The output voltage can be set to 11-15 volts. Thermocouple with the type of $\mathrm{k}$ was utilized in the heat measurements. The electric current generated by the modules was measured with a multimeter. Testing set that was used in the workshop of Automotive Engineering Department of Technology Faculty in Firat University is shown in Figure 5 schematically. TEG cooling system consists of cooling radiator, hoses, tank and electric pump with $12 \mathrm{~V}$ DC voltages. Hydraulic dynamometer that controls the speed and load values of diesel engine is connected in order to determine the performance of TEG system placed between the exhaust manifold and the muffler.
Electric connection of the 40-piece thermoelectric modules mounted on the octagon structure made from Aluminium 6061 material is made in series. The electrical circuit diagrams of TEG are shown in Figure 6.

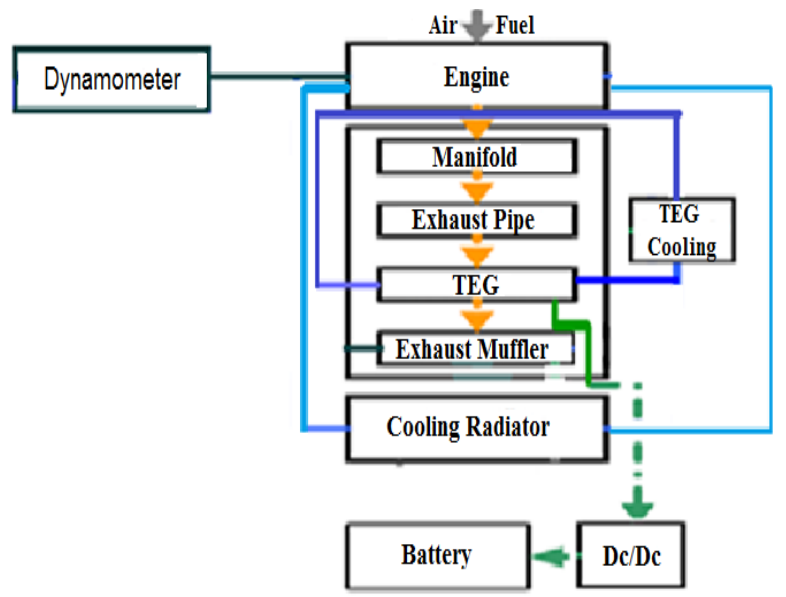

Figure 5: A typical waste heat energy recovery system.

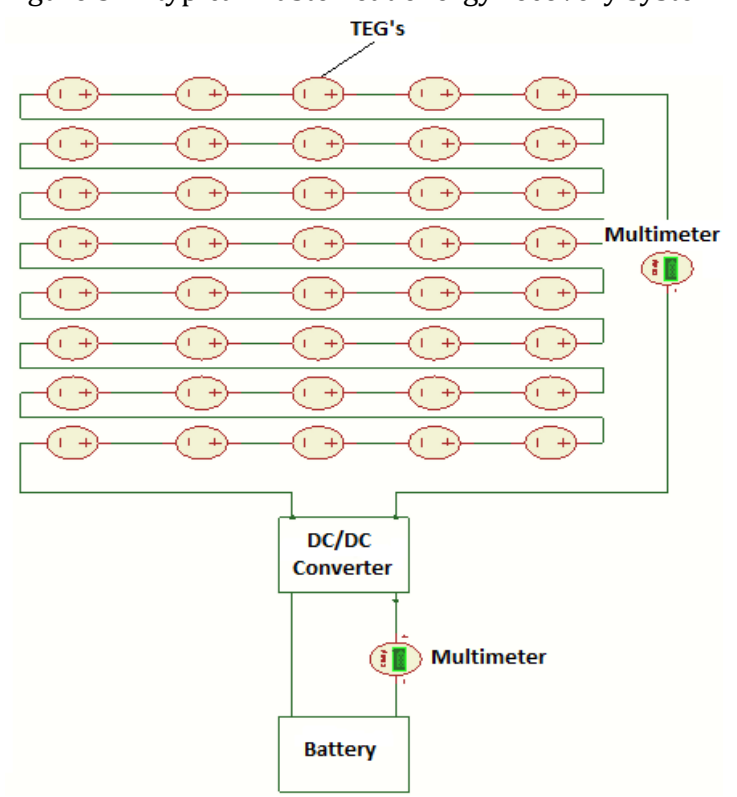

Figure 6: The electrical circuit diagrams of TEG.

\section{Results and discussion}

After TEG system whose connection with engine exhaust system and measurement device was accomplished is ready to operate, it has been aimed that the engine should operate in 15 minutes in order to reach the operating temperature of the engine. It has been observed that there was no failure by reviewing the system at the end of this process. After the engine runs at low speeds, the measurements have been in the range of 1500, 2000, 2500, 3000 and $3500 \mathrm{rpm}$. The effect of the changing engine speed and loads on TEG system was observed by running the engine in the loads of 50 N.m, 75 N.m and 100 N.m in each speed. The amount of filler and heat energy produced shows an increase. As a result of this, the exhaust gas temperatures increases. The input and output temperature of exhaust gases are shown respectively in Figure 7 and Figure 8. When the results are examined, maximum exhaust gas temperature is obtained by running the engine in $100 \mathrm{~N} . \mathrm{m}$ load and in $3500 \mathrm{rpm}$. 


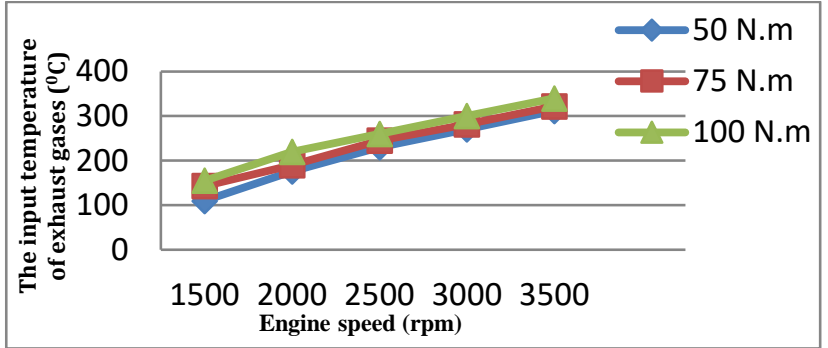

Figure7: The input temperature of exhaust gases.

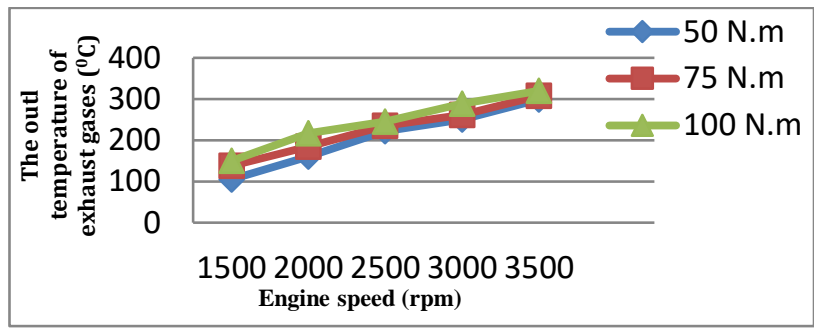

Figure 8: The outlet temperature of exhaust gases.

The temperature of exhaust gases in TEG system have been decreased as a result of convective heat and cooling fluid in TEG system. Exhaust gas temperatures in TEG systems have increased with the increase of the speed and load of the engine. The important parameter for this system is the heat of cool side because the electrical power produced with the increase of the difference of heat tends to increase, too. Therefore, the water is that is circulated with the help of electrical pump in the system has helped the cold surface temperature to reduce. The increase of input temperature of the cooling water is prevented with the help of the cooling fan and heat exchanger. Exhaust gas heats caused the heat of cooling water to increase in parallel with the number of speeds and loads of the engine.

The input temperature of cooling water that varies for depending on different working hours are given in Table 3.

Table 3: The input temperature of cooling water.

\begin{tabular}{cccc}
\hline $\begin{array}{c}\text { Engine Speed } \\
(\mathrm{rpm})\end{array}$ & \multicolumn{3}{c}{ Engine Load } \\
\cline { 2 - 4 } 1500 & $50 \mathrm{~N} \cdot \mathrm{m}$ & $75 \mathrm{~N} . \mathrm{m}$ & $100 \mathrm{~N} . \mathrm{m}$ \\
\hline 2000 & $33.5^{\circ} \mathrm{C}$ & $26^{\circ} \mathrm{C}$ & $30{ }^{\circ} \mathrm{C}$ \\
2500 & $43.2^{\circ} \mathrm{C}$ & $36.8^{\circ} \mathrm{C}$ & $40{ }^{\circ} \mathrm{C}$ \\
3000 & $50.4{ }^{\circ} \mathrm{C}$ & $55^{\circ} \mathrm{C}$ & $48{ }^{\circ} \mathrm{C}$ \\
3500 & $55^{\circ} \mathrm{C}$ & $57.2^{\circ} \mathrm{C}$ & $53.1{ }^{\circ} \mathrm{C}$ \\
\hline
\end{tabular}

As shown in Figure 9, Figure 10 and Figure 11, continuously changing exhaust gas temperatures have caused different temperatures to be created in both surfaces of TEM. The maximum module temperature that occurs when the engine runs in $3500 \mathrm{rpm}$ and $100 \mathrm{~N} . \mathrm{m}$ load has been measured as 258 ${ }^{\circ} \mathrm{C}$ in hot surface and $105{ }^{\circ} \mathrm{C}$ in cold surface. Even if the temperatures of both hot and cold surfaces change for TEM performance, it passes to the steady state after a set of certain state structures. In the study, temperature measurements have been recorded with the help of thermocouples placed on the surfaces of TEM. The temperatures on the hot surface of TEM in 50 N.m engine load and the speeds of $1500,2000,2500,3000$ and $3500 \mathrm{rpm}$ are respectively $80^{\circ} \mathrm{C}, 120{ }^{\circ} \mathrm{C}, 168^{\circ} \mathrm{C}, 196^{\circ} \mathrm{C}$ and $235^{\circ} \mathrm{C}$. It has been measured respectively as $40^{\circ} \mathrm{C}, 56^{\circ} \mathrm{C}, 65^{\circ} \mathrm{C}$,
$80{ }^{\circ} \mathrm{C}$ and $90{ }^{\circ} \mathrm{C}$ in the engine speeds of $1500,2000,2500,3000$ and $3500 \mathrm{rpm}$ in cold surfaces for $50 \mathrm{~N} . \mathrm{m}$ engine load. The increase in the load of the engine has increased both the top and low surface temperatures of TEM. The temperatures on the hot surface of TEM in $75 \mathrm{~N} . \mathrm{m}$ engine load and the speeds of $1500,2000,2500,3000$ and $3500 \mathrm{rpm}$ are respectively $89^{\circ} \mathrm{C}$, $134{ }^{\circ} \mathrm{C}, 170^{\circ} \mathrm{C}, 200{ }^{\circ} \mathrm{C}$ ve $240{ }^{\circ} \mathrm{C}$. It has been measured as respectively $44^{\circ} \mathrm{C}, 60{ }^{\circ} \mathrm{C}, 69^{\circ} \mathrm{C}, 83^{\circ} \mathrm{C}$ ve $95{ }^{\circ} \mathrm{C}$ in the engine speeds of 1500, 2000, 2500, 3000 and $3500 \mathrm{rpm}$ in cold surfaces for 75 N.m engine load. Finally, The temperatures on the hot surface of TEM in 100 N.m engine load and the speeds of $1500,2000,2500,3000$ and $3500 \mathrm{rpm}$ are respectively $95^{\circ} \mathrm{C}, 153^{\circ} \mathrm{C}, 180^{\circ} \mathrm{C}, 220^{\circ} \mathrm{C}$ ve $258^{\circ} \mathrm{C}$. It has been measured as respectively as $49{ }^{\circ} \mathrm{C}, 61{ }^{\circ} \mathrm{C}, 74{ }^{\circ} \mathrm{C}, 88^{\circ} \mathrm{C}$ ve $105^{\circ} \mathrm{C}$ in the engine speeds of 1500, 2000, 2500, 3000 and $3500 \mathrm{rpm}$ in cold surfaces for 100 N.m engine load.

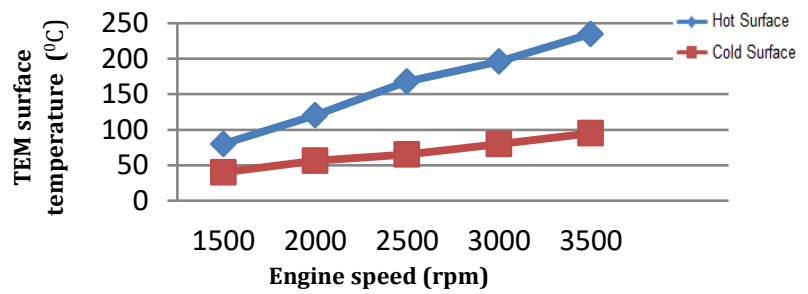

Figure 9: The temperatures on the surface of TEM in 50 N.m engine load.

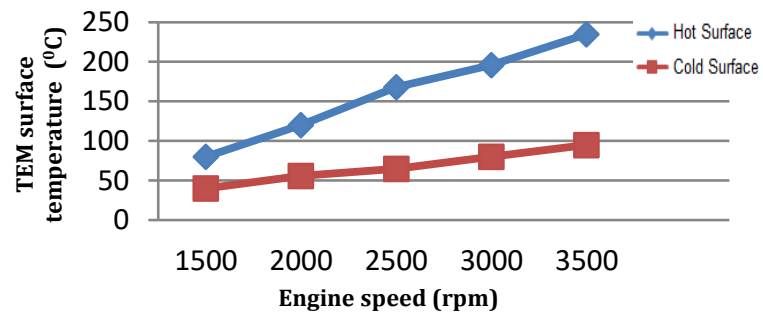

Figure 10: The temperatures on the surface of TEM in 75 N.m engine load.

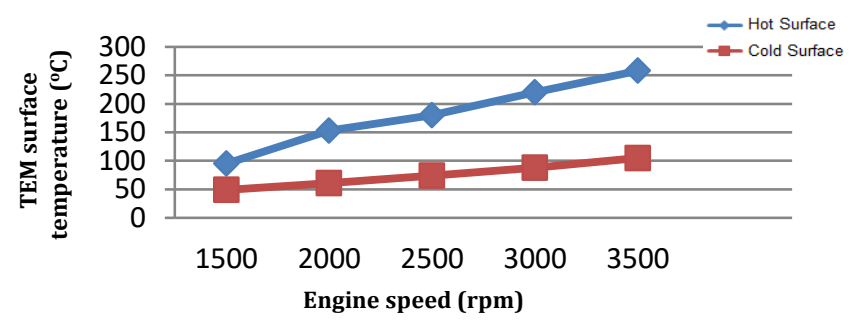

Figure 11: The temperatures on the surface of TEM in 100 N.m engine load.

Number of engine speed and unit time as well as number of speed and piston speed increase in internal combustion engines. Together with these increases, it caused the exhaust has temperature and the exhaust gas flow rate to increase. In the experimental studies, the exhaust flow rate and the temperature is in proportion with the engine speed number. Looking at the results, the situation of the engine load is excessive on the exhaust gas temperatures. The electrical energy production shows a parallel increase with the waste exhaust gas energy.

\subsection{Battery charge with the produced electrical power}

It is important to store the electrical power in maximum power of battery. As in the alternator system, electrical circuit 
elements are needed to charge the battery in our study. Maximum battery charge has been achieved by using DC-DC converter. It has also been used in order to reduce DC voltage and stabilize the electrical energy. The system has been connected to the car battery that has a volt capacity of 12 with the help of DC/DC converter. Thus, the values of current and voltage have been determined in the electrical load of TEG system. DC/DC converter requires setting $14 \mathrm{~V}$ value in order to charge the battery. However, output voltage of TEG should be the value between working voltage of convertor in order to charge the battery. When we examine the results of the experiment, battery charging hasn't been realized for $1500 \mathrm{rpm}$ of the engine because the output voltage of TEG is lower than $19 \mathrm{~V}$. This is about the features of convertor. Battery charging current has been recorded as 1.02, 2.17, 4.81 and $8.53 \mathrm{~A}$ in the speeds of 2000, 2500, 3000 and $3500 \mathrm{rpm}$ in the engine load of 50 N.m. It has been recorded as 1.21, 2.44, 5.79 and $9.12 \mathrm{~A}$ in the speeds of 2000, 2500,3000 and $3500 \mathrm{rpm}$ in the engine load of $75 \mathrm{~N} . \mathrm{m}$. This value has been recorded as 1.87, 2.96, 7.31 and $9.51 \mathrm{~A}$ in the speeds of 2000, 2500, 3000 and $3500 \mathrm{rpm}$ in the engine load of $100 \mathrm{~N} . \mathrm{m}$. The Battery charging current and voltage as a function engine speed for 50 N.m, 75 N.m and 100 N.m Engine loads are shown respectively in Figure 12, Figure 13 and Figure 14. Maximum power storing and balancing have been provided with the help of DC/DC convertor. An amount of power reducing has taken place because of the losses in the circuits. When the results of the experiment are examined we can say that DC/DC convertor runs with $85 \%$ efficiency.

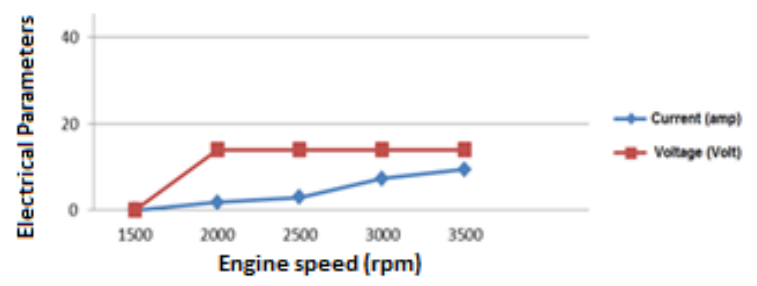

Figure 12: The Battery charging current and voltage as a function engine speed for 50 N.m Engine load.

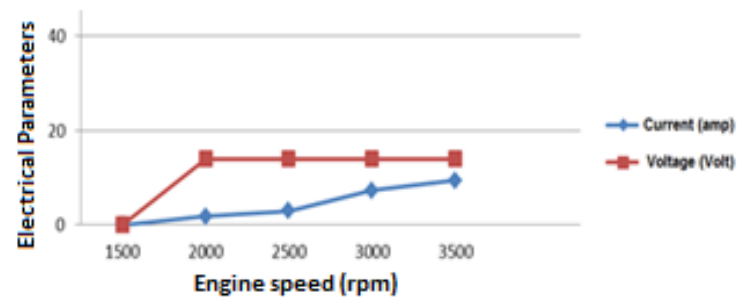

Figure 13: The Battery charging current and voltage as a function engine speed for 75 N.m Engine load.

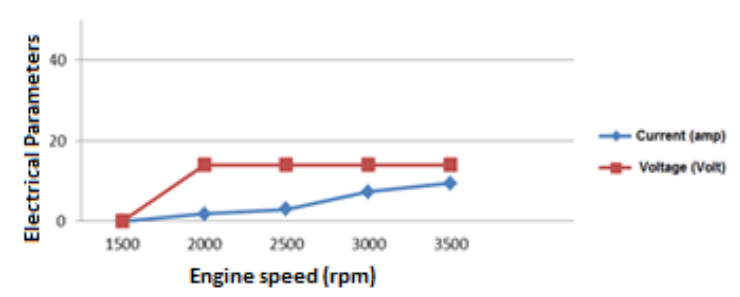

Figure 14: The Battery charging current and voltage as a function engine speed for 100 N.m Engine load.

TEG systems can be more useful for the evaluation of waste heat like vehicle radiators, stoves, natural hot springs, gas water heaters and sun rays. It can be thought as an alternative charging system for the battery charge in hybrid electrical vehicles. The catalytic converter system reduces a large portion of $\mathrm{CO}$ and $\mathrm{HC}$ emissions that occur during the driving. But its performances are limited by the operating temperature. The system cannot work properly until reaching the working heat. Working heat occurs after 1 or 2 minutes and the system starts to work more effectively. The device with thermoelectric can increase the working heat of catalytic converter by reducing the cold start emissions. The studies in the field of internal combustion engines contribute the using of TE materials that provide the energy in exhaust gas into electric energy. The electric produced by these systems can be used effectively by combining with hybrid systems (photovoltaic, piezoelectric). It is not possible for vehicles to work in maximum power while the maximum recover of energy can be provided in the maximum output power of the engine. For this reason, it is possible to conduct some studies in the condition of real way in order to obtain more useful data about the recovery of the energy.

\section{Conclusions}

Thermoelectric power production is a form of converting the waste heat energy into the electric energy. In other words, it is converting the heat between the hot and cold surfaces of semiconductor into electric energy. Testing apparatus has been designed according to this explanation. The one disadvantage of the system is electric energy that is spent for TEG cooling system. The pump and fan have spent electric energy with total of $20 \mathrm{~W}$. In this study, recovery of waste heat has been realized with the help of TEG system connected to exhaust system of diesel energy under different speed and loads. In the study, maximum current and voltage have been obtained as a result of working under 100 N.m load and 3500 rpm. Maximum energy of TEG system has been measured as maximum $156.7 \mathrm{~W}$. This study has revealed that alternator can be alternative energy source in supplying electric energy for receivers such as air conditioner, heater and lamps in the vehicles.

\section{Acknowledgements}

Authors are thankful to Firat University Scientific and research fund for their valuable financial support with the project number TEF.13.03.

\section{References}

[1] Temizer İ, İlkılıç C, Tanyeri B, Ömer C. "Effects on vehicle systems of technology thermoelectric". Batman University Journal of Life Sciences, 1(2), 199-209, 2012

[2] Niu X, Yu J, Wang S. "Experimental study on lowtemperature waste heat thermoelectric generator". Journal of Power Sources, 188(2), 621-626, 2009.

[3] Liang G, Zhou J, Huang X. "Analytical model of parallel thermoelectric generator". Applied Energy, 88(12), 5193-5199, 2011.

[4] Balcı C. Climatization of a Vehicle Cabinet by an $\mathrm{NH}_{3}-\mathrm{H}_{2} \mathrm{O}$ Absorption System Performing with Exhaust Gas Energy. Süleyman Demirel University, Institute of Science and Technology, 2011.

[5] Bağırov H, Can İ, Kapıcıoğlu A. "Stratified charge flame ignite in a gasoline engine conform to the engine operating regimes of indicator of combustion characteristics and burn time and their empirical equations". Tem Journal, 3(1), 55-58, 2014. 
[6] Milli Eğitim Bakanlığı."Emisyon Azaltıcı Sistemler". http://www.megep.meb.gov.tr/mte_program_modul/mo duller_pdf/Egzoz\%20Emisyon\%20Kontrol\%C3\%BC.pdf (14.07.2014)

[7] Ivankovic R, Cros J, Kakhki MT, Martins CA, Viarouge P. "Power electronic solutions to improve the performance of lundell automotive alternators". New Advances in Vehicular Technology and Automotive Engineering, 978953-51-0698-2, 2012.

[8] Ramesh Kumar C, Sonthalia A, Goel R. "Experimental study on waste heat recovery from an IC engine using thermoelectric technology". Thermal Science, 15(4), 1011-1022, 2011.

[9] Hsu CT, Huang GY, Chu HS, Yu B, Yao DJ. "An effective Seebeck coefficient obtained by experimental results of a thermoelectric generator modüle". Applied Energy, 88(12), 5173-5179, 2011.

[10] Hsu CT, Huang GY, Chu HS, Yu B, Yao DJ. "Experiments and simulations on low-temperature waste heat harvesting system by thermoelectric power generators". Applied Energy, 88(4), 1291-1297, 2011.

[11] Yang J. "Potential applications of thermoelectric waste heat recovery in the automotive industry". 24th International Conference on Thermoelectrics, USA, 19-23 June 2005.

[12] Kühn R, Koeppen 0, Kitte J. "Influence of an optimized thermoelectric generator on the back pressure of the subsequent exhaust gas system of a vehicle". Journal of Electronic Materials, 15(4), 1521-1526, 2013.

[13] Kober M. "Methodical concept development of automotive thermoelectric generators (TEG)". $3^{\text {rd }}$ International Conference Thermoelectric goes Automotive, Berlin, Germany, 21-23 November 2012.

[14] Incropera FP, DeWitt DP. Fundamentals of Heat and Mass Transfer. $4^{\text {th }}$ ed, USA, John Wiley \& Sons, 2007.

[15] Vázquez J, Sanz-Bobi MA, Palacios R, Arenas A. "State of the art of thermoelectric generators based on heat recovered from the exhaust gases of automobiles", Universidad Pontificia Comillas , 23 -28015, 2002.

[16] Kaya AY. Experimental Research of Thermoelectric System that Worked by the Heat on Exhaust Gas, MSc Thesis, Süleyman Demirel University, Isparta, Turkey, 2010.

[17] Braig T, Ungethüm J. "System-level modeling of an ICEpowered vehicle with thermoelectric waste-heatutilization". $7^{\text {th }}$ Modelica Conference, Como, Italy, 20-22 September 2009.

[18] Wojciechowski K. Merkisz J. Fuć P. Lijewski P. Schmidt M. "Study of recovery of waste heat from the exhaust of automotive engine" Poznan University of Technology, Piotrowo 3, 60-965, 2007.

[19] Gurbuz H, Akcay H. "Experimental investigation of an improved exhaust recovery system for liquid petroleum gas fueled spark ignition engine". Thermal Science, 19(6), 2049-2064, 2015.
[20] Liu C, Chen P, Li K. "A 1 KW thermoelectric generator for low-temperature geothermal resources". 39th Workshop on Geothermal Reservoir Engineering, Stanford, California, USA, 24-26 February 2014.

[21] Derun EM. A Study on Thermoelectrical, Structural and Microstructural Properties of $\mathrm{Sb} 2 \mathrm{Te} 3$ and $\mathrm{Bi}_{2} \mathrm{Te}_{3}$ Semiconductive Alloys. MSc Thesis, Yıldız Technical University, Istanbul, Turkye, 2005.

[22] Zhang Y, Cleary M, Wang X, Kempf N, Schoensee L, Yang J, Meda L. "High-temperature and high-power-density nanostructured thermoelectric generator for automotive waste heat recovery". Energy Conversion and Management, 105, 946-950, 2015.

[23] Crane TD. "Potential thermoelectric applications in diesel vehıcles". 9th Diesel Engine Emissions Reduction (DEER) Conference, Newport, Rhode Island, 25 August 2003.

[24] Yu C. Chau KT. "Thermoelectric automotive waste heat energy recovery using maximum power point tracking". Energy Conversion and Management. 50(6), 1506-1512, 2009.

[25] Love ND, JP. Szybist JP, Sluder CS. “Effect of heat exchanger material and fouling on thermoelectric exhaust heat recovery". Applied Energy, 89(1), 322-328, 2012.

[26] Bensaid S, Brignone M, Ziggiotti A, Specchia S. "High efficiency Thermo-Electric power generator". International Journal of Hydrogen Energy, 37(2), 1385-1398, 2012.

[27] Gao X, Andreasen JS, Chen M, Kaer SK. "Numerical model of a thermoelectric generator with compact plate-fin heat exchanger for high temperature PEM fuel cell exhaust heat recovery". International Journal of Hydrogen Energy. 37(10), 8490-8498, 2012.

[28] Suter C, Jovanovic Z, Steinfeld A. "A 1 kWe thermoelectric stack for geothermal power generation-modeling and geometrical optimization". Applied Energy, 99, 379-385, 2012.

[29] Meng F, Chen L, Sun F. "A numerical model and comparative investigation of a thermoelectric generator with multi-irreversibilities". Energy, 36(5), 3513-3522. 2011.

[30] Huang HS, Weng YC, Chang YW, Chen SL, Ke MT. "Thermoelectric water-cooling device applied to electronic equipment". International Communications in Heat and Mass Transfer, 37(2), 140-146, 2010.

[31] Zhou Y. Energy Harvesting Using a Thermoelectric Generator and Generic Rule Bused Energy Management. For the Degree of Master of Science, Case Western Reserve University, Ohio, 2008.

[32] Temizer i, İlkılıç C." The performance and analysis of the thermoelectric generator system used in diesel engines". Renewable and Sustainable Energy Reviews, 63, 141-151, 2016. 